\title{
ARCHIMEDES
}

\section{Towards evidence based medicine for paediatricians}

\author{
Edited by Bob Phillips
}

Arch Dis Child 2002;87:258-262

For a year now, Archimedes has sought to assist practising clinicians to give the best care to patients and families; paediatricians need to integrate the highest quality scientific evidence with clinical expertise and the opinions of the family ${ }^{1}$ by providing "evidence based" answers to common questions which are not at the forefront of research, but are at the core of practice. In doing this, we are adapting a format which has been successfully developed by Kevin Mackway-Jones and the group at the Emergency Medicine Journal- "BestBets".

A word of warning. The topic summaries are not systematic reviews, though they are as exhaustive as a practising clinician can produce. They make no attempt to statistically aggregate the data, nor search the grey, unpublished literature. What Archimedes offers are practical, best evidence based answers to practical, clinical questions.

The format of Archimedes may be familiar. A description of the clinical setting is followed by a structured clinical question. (These aid in focusing the mind, assisting searching, ${ }^{2}$ and gaining answers. $\left.{ }^{3}\right)$ A brief report of the search used follows - this has been performed in a hierarchical way, to search for the best quality evidence to answer the question. ${ }^{4}$ A table provides a summary of the evidence and key points of the critical appraisal. For further information on critical appraisal, and the measures of effect (such as number needed to treat, NNT) books by Sackett ${ }^{5}$ and Moyer ${ }^{6}$ may help. To pull the information together, a commentary is provided. But to make it all much more accessible, a box provides the clinical bottom lines.

The electronic edition of this journal contains extra information on each of the published Archimedes topics. The papers summarised in tables are linked, by an interactive table, to more detailed appraisals of the studies. Updates to previously published topics will hopefully be available soon from the same site, published as "rapid responses" to the original article.

Bob Phillips, Evidence-based On Call, Centre for Evidence-based Medicine, University Dept of Psychiatry, Warneford Hospital, Headington OX3 7JX, UK; bob.phillips@doctors.org.uk

\section{REFERENCES}

1 Moyer VA, Ellior EJ. Preface. In: Moyer VA, Elliott EJ, Davis RL, et al, eds. Evidence based pediatrics and child health, Issue 1. London: BM Books, 2000.

2 Richardson WS, Wilson MC, Nishikawa J, et al. The well-built clinical question: a key to evidence-based decisions. ACP J Club 1995;123: A12-13.

3 Bergus GR, Randall CS, Sinift SD, et al. Does the structure of clinical questions affect the outcome of curbside consultations with specialty colleagues? Arch Fam Med 2000;9:541-7.

$4 \mathrm{http}$ ://cebm.jr2.ox.ac.uk/docs/levels.htm [accessed April 2001].

5 Sackett DL, Starus S, Richardson WS, et al. Evidence-based medicine. How to practice and teach EBM. San Diego: Harcourt-Brace, 2000.

6 Moyer VA, Elliott EJ, Davis RL, et al, eds. Evidence based pediatrics and child health, Issue 1. London: BM Books, 2000.

\section{The ethics of tiny trials}

In the first issue of Archimedes we looked at evaluating the difference between a trial which showed therapeutic equivalence, and one which failed to show a difference between treatments. With the concentration on lack of answers in this edition, we turn to the ethics of trials.

It is commonly believed that a trial is justified if the clinician honestly does not know whether a study's treatment is likely to be beneficial for the patient in front of them (equipoise). This position can only really be achieved after a thorough systematic review of any existing literature on the subject. Patients should be aware of the risks and benefits of the study, and make an active informed decision to become involved. Any trial which shows an effect, be that positive or negative, can be said to have assisted understanding and the care of others. When a study is too small to be able to give a conclusive answer, it merely places some patients at risk of adverse effects, others may be denied an advantageous therapy, and both have been deceived into believing their efforts will help other patients. Such studies waste resources (not least the time of the investigators) and may muddy the waters surrounding the therapy with claims of "no effect was shown". As has been previously asserted,' ethics committees should discard trials too small to show an effect.

1 Diulbegovic B, Clarke M. Scientific and ethical issues in equivalence trials. JAMA 2001;285:1206-8.

In this anniversary issue, we highlight four questions which Archimedes considers should have evidence based answersbut don't. These are:

- How quickly can you withdraw antiepileptic medicines?

- Does melatonin help developmentally delayed children with sleep problems?

- Should children with glue ear get grommets (ventilation tubes)?

- Are children with perianal dermatitis more likely to have been sexually abused?

Readers wishing to submit their own questions-with best evidence answers, or indeed lack of answers-are encouraged to review those already proposed at www.bestbets.org. If your question still hasn't been answered, feel free to submit your summary according to the Instructions for Authors at www.archdischild.com.

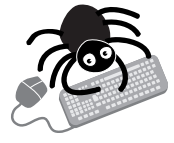

Additional information on each of the topics is available on the $A D C$ website (www.archdischild.com) 
Table 1 Discontinuing anticonvulsant medication

\begin{tabular}{|c|c|c|c|c|}
\hline Citation & Study group & $\begin{array}{l}\text { Study type (level of } \\
\text { evidence) }\end{array}$ & Outcome & Key results \\
\hline Tennison et al (1994) & $\begin{array}{l}149 \text { children with epilepsy } \\
\text { randomised to } 6 \text { week or } 9 \\
\text { month taper after } 2 \text { or } 4 \text { year } \\
\text { seizure free interval }\end{array}$ & $\begin{array}{l}\text { Prospective, randomised } \\
\text { unblinded trial (level } 1 \mathrm{~b} \text { ) }\end{array}$ & Seizure recurrence & $\begin{array}{l}\text { No difference in seizure } \\
\text { recurrence rate between } 6 \\
\text { week and } 9 \text { month taper } \\
(p=0.38) \text { Relative risk } \\
\text { reduction }=8 \% 95 \% \mathrm{Cl} \\
-34 \% \text { to }+50 \%\end{array}$ \\
\hline
\end{tabular}

\section{Discontinuing anticonvulsant medication in children}

\section{Report by Robert Smith and Robin Ball, Consultant Paediatricians, York District Hospital, UK}

A 12 year old girl with primary generalised epilepsy comes to clinic for review. She has been seizure free for two years on sodium valproate $600 \mathrm{mg}$ twice daily. Following discussion with her and her mother, an agreement is reached to withdraw the medication. You advise that the medication should be tapered off over a six week period. At this point the mother informs you that when she had her own anticonvulsant medication withdrawn, this was reduced over a six month period. She questioned whether it was appropriate to reduce the medication so quickly and requested evidence to support the recommendation, raising concerns about the possibility of a higher risk of seizure recurrence.

\section{Structured clinical question}

In a child with primary generalised epilepsy [patient] does the rate of withdrawal of anticonvulsants [intervention] affect rate of seizure recurrence or other adverse event [outcome]?

\section{Search strategy and outcome}

The Cochrane library ${ }^{1}$ search terms "epilepsy" or "anticonvulsants" yielded no relevant systematic reviews or controlled trials of relevance.

Using PubMed-“anticonvulsants/administration and dosage"(MESH) AND “drug administration schedule" (MESH) limits All child 0-18 years, English, clinical trial. There were 98 hits-one relevant RCT was found.

A further search by Ovid 1966-2001 with search terms "anticonvulsants" OR "epilepsy" (MESH) AND "discontinuing" OR "stopping" OR "withdrawal" (keyword) limited to all child $0-18$ was performed. There were 56 hits, the same single RCT was identified. See table 1.

\section{Commentary}

Guidelines based on expert recommendations from the 1980s for adults and children suggested discontinuation be undertaken slowly over a period of months to minimise risk of relapse $^{3}$ (level 5 evidence $^{4}$ ). A large textbook of paediatric neurology gave neither advice nor data. ${ }^{5}$ A general paediatric text suggested weaning should take place over 3-6 months because abrupt withdrawal may cause status epilepticus ${ }^{6}$ (level 5 evidence). The usual practice of two consultant paediatricians, one with an interest in epilepsy, was to withdraw therapy when appropriate over $6-8$ weeks.

There is a paucity of published randomised controlled trials on this subject. The seizure recurrence rate in children in this study was $40 \%$, which is in the range of seizure recurrence rates $(11-41 \%)^{7}$ seen in children but on the higher side. This may reflect a patient population in a tertiary centre with more severe epilepsy. The study identified was relatively small and therefore underpowered to detect potential differences as indicated by the wide confidence intervals. This would especially be so for detecting differences in subgroups of children with differing types of epilepsy and on different anticonvulsants. To confirm an absolute risk reduction of $9 \%$, a significance level of 0.05 and power of $80 \%$ would require 465 subjects in each group, clearly a much larger study.

In this study the type of medication being tapered did not affect risk of seizure recurrence. The majority of patients in both groups were on either phenobarbitone or phenytoin; $66 \%$ in six week taper group and $65 \%$ in nine month taper group. There were only $9 \%$ and $8 \%$ in the respective groups on sodium valproate. There are differences in the pharmacology of these drugs which may affect rates of seizure recurrence on withdrawal. Currently, neither phenytoin and phenobarbitone are first or second choice anticonvulsants used by paediatricians in the UK.

They also randomised into two groups for duration of seizure free period (either two or four years seizure free) before tapering was begun. There was a trend towards a greater risk of seizure recurrence in the group that had been seizure free for two years before drug tapering was begun, although this was not significant. The optimum duration of treatment when seizure control has been achieved has not been established. ${ }^{8}$

The presence of mental retardation and the presence of spikes on pre-withdrawal electroencephalogram increased the likelihood of a recurrence of seizures in this and other studies. Our case had normal intelligence and it is not our routine practice to perform withdrawal electroencephalograms in patients with primary generalised epilepsy.

The subject of this enquiry was tapered off valproate over six weeks and has remained seizure free at three month follow up.

\section{CLINICAL BOTTOM LINE}

- Many factors need to be taken into consideration when considering withdrawing anticonvulsant medication in children with epilepsy; not least the views of the parents and child, which often do not accord with their physician's view. ${ }^{9}$

- With regard to the rate of withdrawal of anticonvulsants for a child with primary generalised epilepsy, this study indicated that tapering treatment over six weeks did not give a significantly higher risk of recurrence of seizures than tapering over a longer period.

- Further studies are required to determine the specific recurrence risk on withdrawal for sodium valproate.

1 The Cochrane Library. www.nelh.nhs.uk/clibohme/clibip.htm [accessed 14.3.2002]

2 Tennison M, Greenwood R, Lewis D, et al. Discontinuing antiepilpetic drugs in children with epilepsy: a comparison of a six week and a nine month taper period. N Engl J Med 1994;333:1407.

3 Chadwick D. The discontinuation of anti-epileptic therapy. In: Pedley TA, Meldrum B, eds. Recent advances in epilepsy, Vol 2. Edinburgh: Churchill Livingston, 1984:111-25.

4 Oxford Centre for Evidence Based Medicine. Levels of evidence and grades of recommendations. 2001, http://cebm.jr2.ox.ac.uk/docs/ levels.html (accessed 14.03.02). 
5 Acardi J. Diseases of the nervous system in childhood. Oxford: Blackwell Scientific Publications, 1992

6 Chesney RW. Treatment of epilepsy. In: Behrman RE, Kleigman RM, Jenson HB, eds. Nelson textbook of paediatrics. Philadelphia: WB Saunders, 2000: 1819-24.

7 Sander JWAS. Stopping antiepileptic drug treatment. In: Duncan JS Sisodiya SJM, Smalls JE, eds. Epilepsy'99-from science to patient. Oxford: International League Against Epilepsy, 1999.

8 Sirven JI, Sperling M, Wingerchuk DM. Early versus late anti-epileptic drug withdrawal for people with epilepsy in remission (Cochrane review). The Cochrane Library, Issue 2. Oxford: Update Software, 2002

9 Gordon K, MacSween J, Dooley J, et al. Families are content to discontinue anti-epileptic drugs at different risks than their physician. Epilepsia 1996;37:557-62.

\section{Is melatonin likely to help children with neurodevelopmental disability and chronic severe sleep problems?}

\author{
Report by \\ Caroline Willey, Staff Grade Community \\ Paediatrician, Central Manchester PCT, UK \\ Bob Phillips, Associate Fellow, Centre for \\ Evidence-based Medicine, Oxford, UK
}

A girl aged 3 years 6 months has neurofibromatosis with significant visual impairment and mild to moderate learning difficulties. She has always been difficult to settle to sleep and has frequent nocturnal wakenings.

A sleep programme with specific behavioural management techniques has been used, as have sedative medications such as trimeprazine, which caused deterioration in concentration and daytime sleepiness. Should she be tried on melatonin?

\section{Structured clinical question}

In a preschool child with visual impairment and mild to moderate learning difficulties, in whom conventional treatments have failed [patient] is melatonin [intervention] likely to improve her sleep pattern [outcome]?

\section{Search strategy and outcome}

Secondary sources

DARE, Clinical Evidence Dec 2000, Medicines for Children RCPCH 1999-none.

Cochrane Library: Systematic Reviews-0, Abstracts of Reviews of Effectiveness-0, Controlled Trials Register-six papers of which two relevant (same papers found through search detailed below)

Primary sources: Medline 1966 to present-using OVID interface

Melatonin.mp AND Sleep disorders.mp (and exploded) AND Learning disabilities (and exploded) AND.limit to:Children $<0$ to 18 years $>$ Human, English language.

This gave 90 references; all titles checked-15 considered, six included. Nine excluded as three non-systematic reviews, two other conditions, one non-delayed children, one slow release melatonin, two abstracts only.

Embase 1980 to present: searched with same strategy-no additional papers.

See table 2 for summary of the six included papers.

\section{Commentary}

Most studies had small numbers of participants with significant drop out rates or non-randomisation in larger studies.
Very few of the studies give $\mathrm{p}$ values or confidence intervalsthey appear far too small to give statistically meaningful effects. One of the trials (Camfield et al) is very different in design, an "N-of-1" study. These trials are designed for each individual patient, and allow for interpersonal variation in drug effect. Classically an N-of- 1 trial has three blocks; during each block the patient receives sequentially therapy and placebo under double blind conditions with an appropriate washout period. Response in two or three blocks is considered positive; less than this, caused by chance alone.

Even allowing for the difficulty of recruitment and objective assessment of outcomes in children with multiple difficulties, there is currently little good quality evidence for the effectiveness of melatonin. The startling increase in seizures noted by the Sheldon paper is of great concern, especially in the UK where melatonin is often given in an uncontrolled way with overseas imports of the drug. A large multicentre placebo controlled randomised controlled trial is needed to try to clarify which children and what types of sleep disorder are most amenable to treatment, and to define the likely side effect profile.

- CLINICAL BOTTOM LINE

- Melatonin may be effective in sleep onset difficulties, but not in fragmented sleep or early morning wakening, though evidence is poor quality.

- There is little evidence regarding melatonin's long term safety profile.

- Melatonin should be used with caution in any child with epilepsy in view of increased seizure frequency in one study; "N-of-1" methods may be considered.

Jan JE, Espezel H, Appleton RE. The treatment of sleep disorders with melatonin. Dev Med Child Neurol 1994;36:97-107.

Camfield P, Gordon K, Dooley J, et al. Melatonin appears ineffective in children with intellectual deficits and fragmented sleep: six " $\mathrm{N}$ of 1 " trials. J Child Neurol 1996;11:341-3

Palm L, Blennow G, Wetterberg L. Long-term melatonin treatment in blind children and young adults with circadian sleep-wake disturbances. Dev Med Child Neurol 1997:39:319-25.

Sheldon SH. Pro-convulsant effects of oral melatonin in neurologically disabled children. Lancet 1998;351:1254

O'Callaghan FJ, Clarke AA, Hancock E, et al. Use of melatonin to treat sleep disorders in tuberous sclerosis. Dev Med Child Neurol 1999;41:123-6.

Dodge NN, Wilson GA. Melatonin for treatment of sleep disorders in children with developmental disabilities. J Child Neurol $2001 ; 16: 581-4$

\section{Do grommets prevent language delay?}

\section{Report by}

Vidya Sudhakar-Krishnan, Paediatric Registrar, St James's University Hospital, Leeds, UK

Mary Rudolf, Consultant Community

Paediatrician, Leeds General Infirmary, Leeds, UK

A mother brings her 2 year old daughter to your clinic. She is concerned about her speech which she feels is poor for her age. Her daughter has failed two consecutive audiograms. On otoscopy she has signs of bilateral otitis media with effusion (OME) which you have confirmed on a previous occasion two months ago. Should you refer for insertion of grommets?

\section{Structured clinical question}

In preschool children with OME (glue ear) [patient] does the insertion of ventilation tubes (grommets) [intervention] as 


\begin{tabular}{|c|c|c|c|c|c|}
\hline Citation & Study group & Level of evidence & Outcomes & Key results & Comments \\
\hline Jan et al (1994) & $\begin{array}{l}15 \text { children aged } 6 \mathrm{mth} \\
\text { to } 14 \mathrm{y} \text {, mean } 6.8 \mathrm{y} \\
\text { Most multiply disabled; } 5 \\
\text { with epilepsy, } 9 \text { visually } \\
\text { impaired } \\
\text { Melatonin } 2.5-5 \mathrm{mg}\end{array}$ & $\begin{array}{l}\text { Double blind placebo } \\
\text { controlled trial (level 1b); } \\
\text { crossover study }\end{array}$ & $\begin{array}{l}\text { Sleep charts } \\
\text { Parental interview }\end{array}$ & $\begin{array}{l}\text { No adverse effects } \\
\text { No response in } 2 / 15 \\
1 \text { child-ceased effect even } \\
\text { with } 20 \text { mg after } 6 \text { mth }\end{array}$ & $\begin{array}{l}6(40 \%) \text { not randomised } \\
\text { Type of sleep } \\
\text { disturbance described }\end{array}$ \\
\hline $\begin{array}{l}\text { O'Callaghan et al } \\
\text { (1999) }\end{array}$ & $\begin{array}{l}7 \text { children aged } 2-28 \text { y } \\
\text { with tuberose sclerosis } \\
\text { with epilepsy + SLD } \\
\text { Randomised to placebo } \\
\text { or } 5 \mathrm{mg} \text { melatonin } 20 \\
\text { min prior to bedtime }\end{array}$ & $\begin{array}{l}\text { Crossover randomised } \\
\text { double blind trial (level } \\
\text { 1b) }\end{array}$ & $\begin{array}{l}\text { Sleep diary } \\
\text { Total sleep time } \\
\text { Sleep onset latency } \\
\text { No. awakenings }\end{array}$ & $\begin{array}{l}\text { Mean improvement in total } \\
\text { sleep time of } 0.55 \mathrm{~h}(\mathrm{Cl} \\
0.088 \text { to } 1.01) \\
\text { No effect on fragmented } \\
\text { sleep } \\
\text { Sleep onset latency } \\
\text { improved but did not reach } \\
\text { significance }\end{array}$ & $\begin{array}{l}\text { Short treatment time for } \\
\text { any adverse effects to } \\
\text { become apparent } \\
\text { No effect noted on } \\
\text { seizure frequency }\end{array}$ \\
\hline $\begin{array}{l}\text { Dodge and Wilson } \\
\text { (2001) }\end{array}$ & $\begin{array}{l}20 \text { children with } \\
\text { moderate to severe } \\
\text { developmental } \\
\text { disabilities ( } 4 / 20 \text { visual } \\
\text { impairment); age range } \\
1-12 \text { years } \\
36 \text { recruited but only } 20 \\
\text { completed study }\end{array}$ & $\begin{array}{l}\text { Randomised double } \\
\text { blind placebo controlled } \\
\text { trial (level 2b) }\end{array}$ & $\begin{array}{l}\text { Sleep latency } \\
\text { Duration of sleep } \\
\text { No. awakenings } \\
\text { Sleep log and } \\
\text { parental questionnaire }\end{array}$ & $\begin{array}{l}\text { Sleep latency improved in } \\
\text { all but } 2 \text { children on MLT } \\
\text { ( } p<0.05) ; \text { more marked in } \\
\text { those with greater sleep } \\
\text { latency on baseline } \\
\text { measure } \\
\text { Duration of sleep improved } \\
\text { with MLT but no different } \\
\text { from placebo } \\
\text { No change in number of } \\
\text { wakenings }\end{array}$ & $\begin{array}{l}\text { No side effects reported } \\
\text { Large drop out rate but } \\
\text { no reported differences } \\
\text { in diagnosis, age, } \\
\text { epilepsy, etc in those not } \\
\text { completing } \\
\text { No baseline data for } \\
\text { type or severity of sleep } \\
\text { problems in those } \\
\text { dropping out }\end{array}$ \\
\hline Camfield et al (1996) & $\begin{array}{l}6 \text { children aged 3-13 y } \\
\text { Blind with at least } \\
\text { moderate learning } \\
\text { disability, using } 0.5-1 \\
\text { mg melatonin }\end{array}$ & $\begin{array}{l}\text { "N-of-1" double blind } \\
\text { placebo trial (level 2b) }\end{array}$ & $\begin{array}{l}\text { Sleep diary } \\
\text { Average numbers } \\
\text { hours sleep per } 24 \\
\text { hours } \\
\text { Number of wakenings } \\
\text { between } 9 \text { pm and } 7 \\
\text { am } \\
\text { Number of nights } \\
\text { without wakening } \\
\text { between } 10 \text { pm and } 7 \\
\text { am }\end{array}$ & $\begin{array}{l}\text { Found MLT to be ineffective } \\
\text { in } 5 / 6\end{array}$ & $\begin{array}{l}\text { Low dose used } \\
\text { Timing in relation to } \\
\text { desired sleep time may } \\
\text { have been too long } \\
\text { No adverse effects noted } \\
\text { No information about } \\
\text { blinding or } \\
\text { randomisation }\end{array}$ \\
\hline Palm et al (1997) & $\begin{array}{l}8 \text { aged } 3-23 \text { y } 16 \\
\text { children aged } 18 \text { or less) } \\
\text { All functionally blind, } \\
M / S \text { learning disabilities } \\
0.5-2 \text { mg melatonin, } \\
\text { age dependent }\end{array}$ & Open study (level 4) & $\begin{array}{l}\text { Sleep diaries for } 6 \\
\text { weeks prior to } \\
\text { treatment and several } \\
\text { months during } \\
\text { treatment } \\
\text { MLT levels in } 7 \\
\text { children }\end{array}$ & $\begin{array}{l}\text { "Dramatic" response in all } \\
8 \\
\text { Loss of effect in } 1 \text { after } 6-8 \\
\text { months } \\
\text { MLT levels showed delayed } \\
\text { peak }\end{array}$ & No side effects reported \\
\hline $\begin{array}{l}\text { Sheldon (1998) } \\
\text { Published as research } \\
\text { letter }\end{array}$ & $\begin{array}{l}6 \text { children, } 9 \text { months to } \\
18 \mathrm{y} \\
\text { Multiple neurological } \\
\text { deficits and chronic sleep } \\
\text { disorders with } 5 \mathrm{mg} \text { at } \\
\text { bedtime }\end{array}$ & $\begin{array}{l}\text { Open study, consecutive } \\
\text { recruitment (level 4) }\end{array}$ & $\begin{array}{l}\text { Wrist actigraph } \\
\text { Changes in sleep } \\
\text { onset latency, } \\
\text { nocturnal wakenings } \\
\text { Total sleep time }\end{array}$ & $\begin{array}{l}\text { Marked improvement in all } \\
3 \text { measures in } 5 / 6\end{array}$ & $\begin{array}{l}\text { Study stopped due to } \\
\text { increased or new seizure } \\
\text { type activity on } \\
\text { melatonin in } 4 / 6 \\
\text { No info on types of AE } \\
\text { meds used }\end{array}$ \\
\hline
\end{tabular}

MLT, melatonin.

opposed to watchful waiting [comparison] have an effect on language development [outcome]?

\section{Search strategy and outcome}

Secondary searches: Cochrane-one relevant protocol (planned systematic review). ${ }^{4}$

Medline 1966 to November 2001, using the OVID interface: "otitis media with effusion", "glue ear" , "otitis media" AND "middle ear ventilation" , "grommets" AND filter "clinical trial" , "controlled clinical trial" , "metanalysis" , "randomized clinical trial " LIMIT to "English language".

Search results -127 articles, three relevant. See table 3.

\section{Commentary}

The use of language development as an outcome measure is problematic because of confounding factors, such as age, maternal education, and comorbid conditions. These studies have attempted to overcome this by randomisation, but still have problems with small study populations leaving the possibility of uneven allocation. The large numbers of the watchful waiting group being treated despite the study protocol may bias the results, reducing the apparent effect of ventilation tubes. These problems need to be taken into consideration when interpreting the studies.

In the UK, screening is not routinely carried out for OME, so the patient population in two of the studies is not similar to the UK population. The inclusion of "asymptomatic" children is likely to reduce the effectiveness of ventilation tubes, should any truly exist. The large unintentional crossover in some studies highlights the major problem in that there are no clear indications for the insertion of grommets.

Taken as a whole, there does seem to be some improvement in language skills a few months after the treatment. It is not evident that these effects persist long term and the differences seem to diminish with time, as one would expect with the natural history of the condition.

As grommet insertion is the most common elective operation in preschool children, concerns both about risks of the anaesthesia and cost-benefit analysis of the procedure need to be addressed. The results of a further randomised controlled trial are awaiting publication.' 
Table 3 Grommets in OME

\begin{tabular}{|c|c|c|c|c|c|}
\hline Citation & Study group & $\begin{array}{l}\text { Study type (level of } \\
\text { evidence) }\end{array}$ & Outcome & Key results & Comments \\
\hline Rach et al (1991) & $\begin{array}{l}\mathrm{n}=52 \\
\text { Age: } 2 \text { year olds } \\
\text { Children from a larger } \\
\text { cohort were screened for } \\
\text { OME with tympanograms } \\
\text { Randomised to treatment }\end{array}$ & $\begin{array}{l}\text { Randomised controlled } \\
\text { trial (level } 2 \text { b) }\end{array}$ & $\begin{array}{l}\text { Improvement in } \\
\text { language scores at } 6 \\
\text { months }\end{array}$ & $\begin{array}{l}\text { Improvement in scores in } \\
\text { the treatment group, but } \\
\text { large overlapping } \mathrm{Cl}\end{array}$ & $\begin{array}{l}\text { Follow up } 100 \% \text {; small } \\
\text { numbers in trial and follow } \\
\text { up time not sufficient } \\
\text { Balanced randomisation } \\
\text { Testers not blinded }\end{array}$ \\
\hline Maw et al (1999) & $\begin{array}{l}\mathrm{n}=182 \\
\text { Age: } 2-3 \text { year olds } \\
\text { Confirmed to have OME } \\
\text { and hearing loss with } \\
\text { tympanograms; only those } \\
\text { with problems in speech, } \\
\text { learning, or behaviour were } \\
\text { included } \\
\text { Randomised to treatment }\end{array}$ & $\begin{array}{l}\text { Randomised controlled } \\
\text { trial (level 2b) }\end{array}$ & $\begin{array}{l}\text { Improvement in } \\
\text { language scores at } 9 \\
\text { and } 18 \text { months }\end{array}$ & $\begin{array}{l}\text { Improvement in treated } \\
\text { group at } 9 \text { months } \\
\text { Mean difference } \\
\text { between groups was not } \\
\text { significant } \\
0.31(-0.03 \text { to } 0.66) \\
95 \% \mathrm{Cl} \\
\text { At } 18 \text { months smaller } \\
\text { differences which were } \\
\text { not significant }\end{array}$ & $\begin{array}{l}\text { Follow up } 83 \% \\
\text { Large drop out in trial } \\
\text { makes results difficult to } \\
\text { interpret; by } 18 \text { months } \\
85 \% \text { of watchful waiting } \\
\text { group had grommets } \\
\text { inserted } \\
\text { Data analysed by intention } \\
\text { to treat }\end{array}$ \\
\hline Rovers et al (2000) & $\begin{array}{l}\mathrm{n}=187 \\
\text { Age: } 16-24 \text { months } \\
\text { From a larger cohort that } \\
\text { were screened for hearing } \\
\text { loss and OME } \\
\text { Randomised to treatment }\end{array}$ & $\begin{array}{l}\text { Randomised controlled } \\
\text { trial (level } 2 \mathrm{~b} \text { ) }\end{array}$ & $\begin{array}{l}\text { Improvement of } \\
\text { language scores at } 6 \\
\text { and } 12 \text { months }\end{array}$ & $\begin{array}{l}\text { No difference between } \\
\text { treatment and watchful } \\
\text { waiting groups }\end{array}$ & $\begin{array}{l}\text { Follow up } 79 \% \\
\text { Balanced allocation for } \\
\text { groups but groups were } \\
\text { different for confounding } \\
\text { factors; not clear if testers } \\
\text { were blinded }\end{array}$ \\
\hline
\end{tabular}

\section{- CLINICAL BOTTOM LINE}

- In children with OME and language delay, there is no good evidence to suggest that insertion of ventilation tubes will improve language development.

- A more important factor is mother's level of education, which has been shown to have a greater effect on language acquisition in young children.

1 Rach GH, Zielhuis GA, Van Baarle PW, et al. The effect of treatment with ventilating tubes on language development in preschool children with otitis media with effusion. Clinical Otolaryngology \& Allied Sciences 1991;16:128-32

2 Maw R, Wilks J, Harvey I, et al. Early surgery compared with watchful waiting for glue ear and effect on language development in preschool children: a randomized controlled trial. Lancet 1999;353:960-3.

3 Rovers $M M$, Straatman $\mathrm{H}$, Ingels $\mathrm{K}$, et al. The effect of ventilation tubes on language devlopment in infants with otitis media with effusion. A randomized contolled trial. Pediatrics 2000;106:E42.

4 Lous J, Burton M, Felding JU, et al. Grommets (ventilation tubes) for hearing loss associated with otitis media with effusion in children (protocol for a Cochrane review). The Cochrane Library, Issue 4. Oxford Update Software, 2001

5 Paradise JL, Dollaghan CA, Campbell TF et al. Language, speech sound production, and cognition in three-year-old children in relation to otitis media in their first three years of life. Pediatrics 2000;105:11119-30.

\section{Is perianal dermatitis a sign of sexual abuse?}

Report by

Joanna Thomas, Staff Grade in Community

Child Health, Leeds Community and Mental

Health Trust, UK

\section{Mary Rudolf, Consultant Paediatrician in Community Child Health, Leeds Community and Mental Health Trust, UK}

Y ou have seen a toddler in clinic, and as a "by the way" on leaving, the mother tells you that the child has a very red bottom and cries on defaecation although she is not constipated. On examination you see the classic signs of perianal dermatitis. You prescribe penicillin, and subsequent culture confirms streptococcal A infection. After clinic the staff grade doctor, who works with you and has expertise in child protection informs you that you should be considering sexual abuse as an issue. You decide to find out if there is an association between perianal dermatitis and child sexual abuse.

\section{Structured clinical question}

In young children [patient] with signs of perianal dermatitis [risk factor] is there an increased likelihood of sexual abuse [outcome]?

\section{Search strategy and outcome \\ Secondary sources: nil.}

Medline: perianal dermatitis.mp or exp anus disease/ or exp anus/ AND sex offenses/ or sexual abuse.mp.

Search results-26 articles found, none relevant.

\section{Commentary}

Nelson's textbook ${ }^{1}$ cites the consideration of child sexual abuse as an association with perianal dermatitis. A search of the literature does not appear to provide any primary evidence to support this association.

\section{- CLINICAL BOTTOM LINE}

- No evidence has been found to support or refute the association of perianal dermatitis and sexual abuse.

1 Behrman RE, Kliegman R, Nelson WE, et al, eds. Nelson's textbook of paediatrics, 15th edn. WB Saunders Co, 1996. 